\title{
Effects of phenobarbital sodium on spontaneous motor activity
}

RICHARD C. NIEMEYER AND SHEPARD SIEGEL UNIVERSITY OF MISSOURI, COLUMBIA

Utilizing a latin square design, rats were injected with 80 , $40,20,10,5$ and 0 (saline control) $\mathrm{mg} / \mathrm{kg}$ phenobarbital sodium prior to assessing spontaneous motor activity. Activity was found to be related to drug dose by an inverted-U shaped function, with maximum activity being observed subsequent to receiving $20 \mathrm{mg} / \mathrm{kg}$. The relationship was reliable across $S \mathrm{~s}$ and from replication to replication.

Previous investigations suggest that low dosages of phenobarbital increase activity, and high doses decrease activity (e.g., Chen \& Bohner, 1960; Kinnard \& Karr, 1957). However, as pointed out by Harris, Pearl, \& Aceto (1966), speculation is needed to draw any firm conclusions about phenobarbital and activity level because the experiments contain such a small range of doses. In an attempt to assess the effects of the drug over a wider dose range, Harris et al (1966) orally medicated groups of mice with either $30,45,90,135$, or $150 \mathrm{mg} / \mathrm{kg}$ of phenobarbital sodium prior to measuring activity. An inverted U-shaped relationship between drug dose and activity was obtained. The purpose of the present investigation was to determine if this relationship would be obtained after parenteral administration of a range of doses of the drug within a single s.

Method

The Ss were 18 experimentally naive, male albino rats, obtained from Holtzman, Inc., Madison, Wis. They ranged in age from 100-110 days at the start of the experiment. All Ss were kept in individual cages and maintained on ad lib food and water throughout the experiment.

Activity measures were made on a Lafayette Activity Platform (Model A-501). With this platform, spontaneous activity on an enclosed 12 in. sq. grid is transduced, via an inductance, to a digital counter.

The experiment was conducted in three identical replications with six Ss in each replication. A withinS design was utilized, in which all Ss were tested at all dose levels. The dosages studied were 0 (saline control), $5,10,20,40$, and $80 \mathrm{mg} / \mathrm{kg}$ of phenobarbital sodium. The injection schedule for each replication was based on a simple latin square design. Each $S$ was injected IP with all six doses, one at a time, at $48 \mathrm{~h}$ intervals. Thirty min after an injection, $\mathrm{S}$ was placed on the activity platform, and activity was monitored for the next $30 \mathrm{~min}$, after which $\mathrm{S}$ was returned to its home cage.

\section{Results and Discussion}

Figure 1 indicates the activity level exhibited by each $\mathbf{S}$ at each dosage level in all three replications.
As may be seen in Fig. 1, activity level for all Ss (with one exception in Replication 3) was related to drug dose by an inverted U-shaped function, with a peak at $20 \mathrm{mg} / \mathrm{kg}$. An analysis of variance on this activity data indicated the effect of drug dose was highly significant $(p<.001)$, with no other main effects or interactions approaching significance.

It would appear that there is a nonmonotonic but highly reliable function relating sodium phenobarbital dose to motor activity.
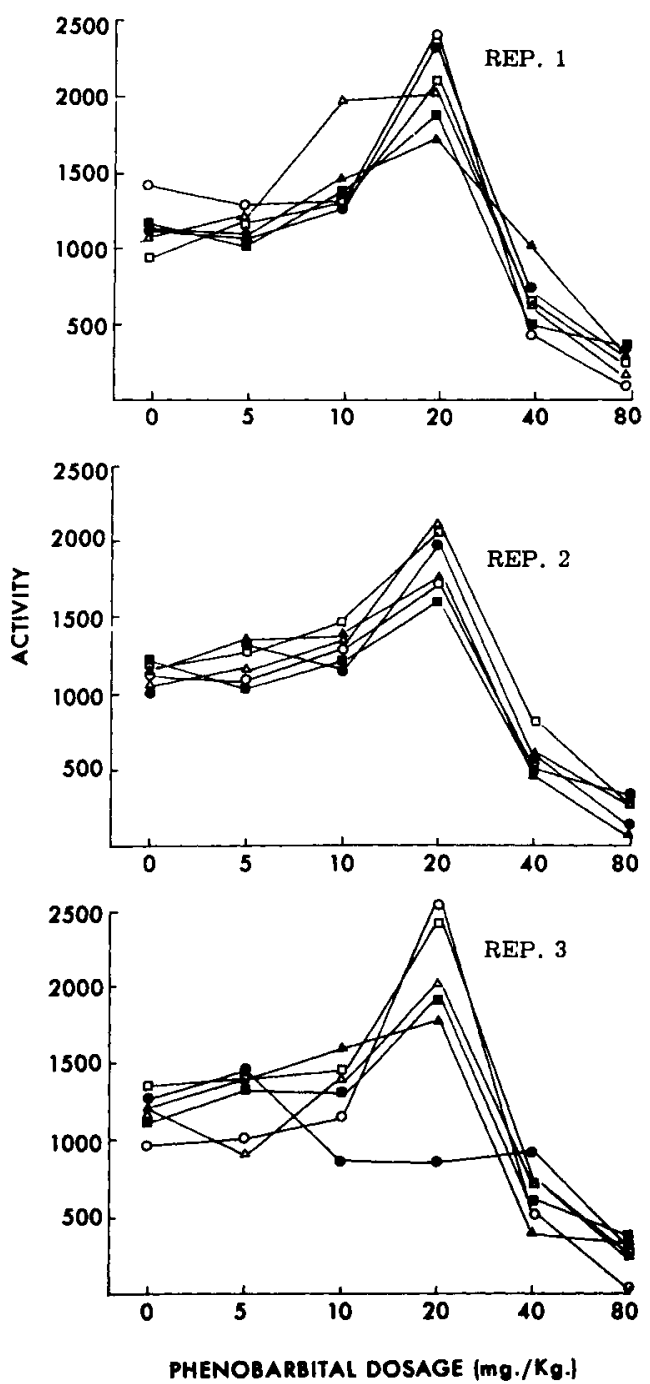

Fig. 1. Motor activity of individual Ss as a function of phenobarbital dose. 


\section{References}

CHEN, G., \& BOHNER, B. A study of certain CNS depressants. Arch int. Pharmacodyn. Ther., 1960, 125, 1-20.

HARRIS, L., PEARL, J., \& ACETO, M. D. Similarities in effects of barbiturates and mild tranquilizers on activity in mice. Psychon. Sci. $1966,6,267-268$.

KINNARD, W. J., Jr., \& KARR, C. J. A preliminary procedure for the evaluation of central nervous system depressants. J. Pharmacol exp. Ther., 1957, 121, 354-361. 